\title{
IMPLEMENTATION OF SPORTS NATIONAL POLICY ON SPORT LEARNERS IN NORTH SUMATRA
}

\author{
Nimrot Manalu \\ State University of Medan \\ putrahumb@yahoo.com
}

\begin{abstract}
The purpose of this research is to get information about the implementation of national sports policy towards student sport in North Sumatra. This research is a qualitative research. The focus of this research is to explore the real situation occurring in the forefront of the national sports and sports policy of North Sumatra students collected by interview method. The result is that there is no harmony between the sports policy and the reality society of sports in North Sumatra. This research gave birth to recommendations such as the need to optimize the socialization of Law No. 3 of 2005, Regulation of Government no. 18,17,18 among physical education teachers and trainers of Sports Students in North Sumatra are communicative, chain and quality. Need to be socialized National sports programs or projects such as the need for guidance or guidance for students' recreational sports, it is necessary to establish guidelines for the establishment of student achievement sports, to optimize the existence of Board of Trustees of Student Sport throughout Indonesia, it is necessary to realize the procurement of sports science and technology in schools that build sport achievement in North Sumatra, it is necessary to realize the establishment of the Student Training Center Training Center at the district / city level, it is necessary to realize the presence of special trainers of sports with the status of civil servants in school schools, and the need to realize sports championships or students' sports week at each level of city districts periodically and continuously.
\end{abstract}

Keywords: National Policy Implementation of Sports, Sports Student

The dynamics of the development of world sporting achievements have been increasing rapidly, which is marked by the increasing competition of countries to become the best and leading in the field of sports. Competition to be the best and foremost is no longer just the ideals of an athlete or coach, but more than that has become the goal of every country. The fact is based on a belief that sporting achievements can have a diverse impact both for the sports actors themselves, the community and even the country. Impacts such as increasing the welfare of sports achievers, the increase of public fitness, the rise of the image of a nation in the international world, and also the increasing value of the nation's economy.

The welfare guarantee of the sportsman is dealing with the end of his career. In other words, an athlete who pursue a career in sports should ultimately Increase the welfare of sports achievers obtained by directly or indirectly will get welfare, especially when no longer active as an athlete.

Athletes or beings who have made such achievements are superior human beings. The appearance of the superior man was unpredictable before, but showed a spectacular ability. In general, the place where humans excel primarily for sports is the school, meaning that students can be positioned as a superior human group. The problem that often arises is whether or not their superiority develops. In other words, the situation is very dependent on the interventions imposed on Referring to the above explanation, so that the goal of human enhancement talented sportsmen run effective and efficient, it takes touch or external intervention in the form of a service approach taking into account the abilities and talents possessed by the student group as a candidate sportswear.

The fact shows that in the last three years of the North Sumatra National Sports Week team, most of them are sported by sportsman in the Student Training Center of North Sumatra, have not done much. Likewise, there is still a lack of contribution from North Sumatra sportsmen who are 
incorporated in North Sumatra the Student Training Center to North Sumatra contingent who competed in National Sports Week East Kalimantan 2008, whereas National Sports Week is a national sports performance testing event. In terms of quantity, the number of the Student Training Center and former the Student Training Center sportsmen who are affiliated with National Sports Week North Sumatra team in East Kalimantan is still relatively small, and in terms of quality, The Student Training Center athletes who are members of National Sports Week North Sumatra team are low. Table 2. shows data about athletes and former sportsmen the Student Training Center North Sumatra who became the ambassador of North Sumatra in National Sports Week XVII year 2008 East Kalimantan.

\section{Data And Facts Of Athlete Achievement The Student Training Center Training Center And Former The Student Training Center Training Center}

\section{North Sumatra National Sports Week Xviii 2008 East Kalimantan}

\begin{tabular}{|l|l|l|l|l|l|l|}
\hline \multirow{2}{*}{ No } & Name & $\begin{array}{c}\text { The Student } \\
\text { Training } \\
\text { Center } \\
\text { Training } \\
\text { Center }\end{array}$ & $\begin{array}{c}\text { Ex. The } \\
\text { Student } \\
\text { Training } \\
\text { Center } \\
\text { Training } \\
\text { Center }\end{array}$ & Sport & Event & Ranking \\
\hline 1 & EH & & $\sqrt{ }$ & Athletics & $1500 \mathrm{~m}$ & \\
\hline 2 & JG & & $\sqrt{ }$ & Athletics & $800 / 1500 \mathrm{~m}$ & 6 and 5 \\
\hline 3. & EW & & $\sqrt{ }$ & Athletics & $100 \mathrm{~m}$ hurdle & 4 \\
\hline 4 & ZP & & $\sqrt{ }$ & Athletics & $110 / 400 \mathrm{~m}$ hurdle & 1 and 2 \\
\hline 5 & NP & & $\sqrt{ }$ & Athletics & $3000 \mathrm{~m}$ st chase & - \\
\hline 6 & HH & & $\sqrt{ }$ & Athletics & $100,200 \mathrm{~m}$ & elimination 7 \\
\hline 7 & AH & & Athletics & $4 \times 100 \mathrm{~m}$ & 7 \\
\hline 8 & ES & $\sqrt{ }$ & $\sqrt{ }$ & Athletics & $4 \times 100 \mathrm{~m}$ & 7 \\
\hline 9 & EK & & & Athletics & $20 \mathrm{~km}$ race walk & 4 \\
\hline 10 & DAF & $\sqrt{ }$ & $\sqrt{ }$ & Arrow & & - \\
\hline 11 & SS & & Wrestling & $60 \mathrm{~kg}$ free style & semifinal \\
\hline
\end{tabular}

\section{Data Source: Deputy Assistant of Nursery and Deputy of Ministry of Youth and Sports} Empowerment Republic of Indonesia

In essence, the student's sport involves three things, namely recreational and educational restoration. And usually sports education or physical education is the first base of student sports activities.

Just like other education, physical education is managed by utilizing the curriculum that has been prepared as an effort to achieve the goal of physical education itself, but physical education is an education that has its own characteristics so easily distinguished from other education. The dominant execution of physical education is to involve the physical or motor ability of the body in order to achieve the goal of education itself, so that the physical and mental totality awakened at the time of physical education.

Sports recreation is a sport that has a recreation aspect means by doing the sport students get the recreation impact as a result of the exercise. Prestigious sports is a sport that is ready to compete or competed on certain events or championships to achieve prestigious results or sports prestige such 
as champions and so forth. Sports achievement is packaged in a structured and continuous activity gradually or progressive which is marked by the performance or appearance that increasingly old. The battle arena or achievement sport achievement is available with a championship or sports meeting such as regional sports clubs to international level.

The national government has outlined its policy on sports as a whole, including the sport of the students and specifically in North Sumatra area. The problem is how the implementation of the national sports policy takes place on student sports as well as the central theme in this research is the national sports policy on the sport of students in North Sumatra.

Based on the background of the problem further formulation of the problem in this research is how the implementation of national sports policy towards sports students in north sumatra. This study aims to first examine the implementation of national sports policy towards sports students in north sumatra and the second gave birth to policy recommendation about student sport.

\section{National Sports System Building}

The building of the Indonesian National Sports system is described as shown in Figure 2.1.

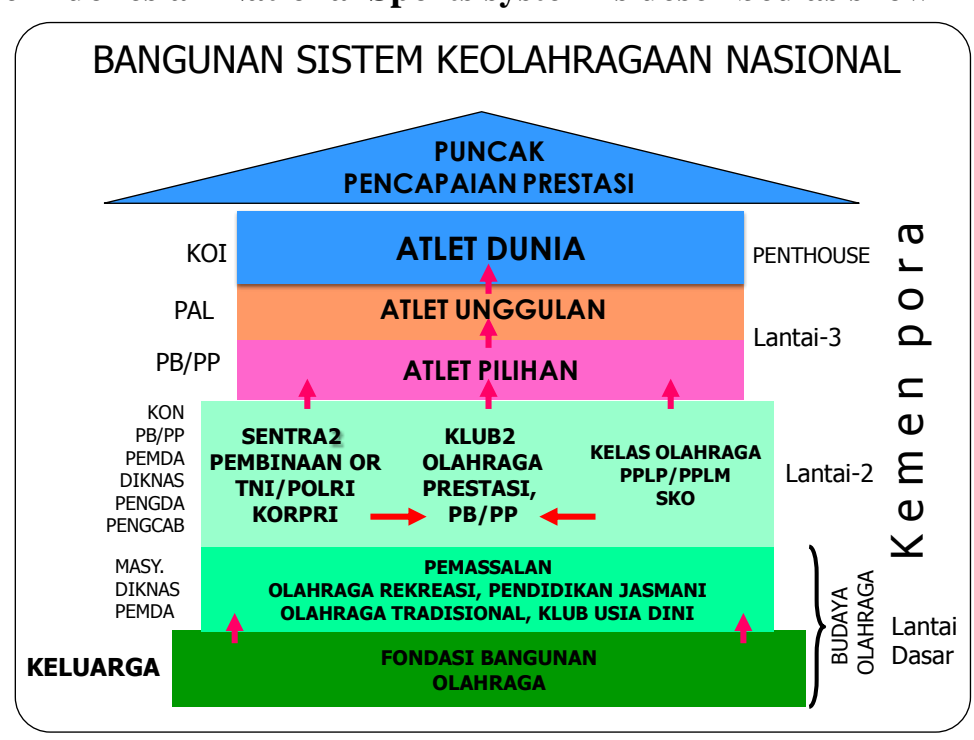

Figure 2.1 National Sports System Building

Source: National Sporting Agency Governance Guide Ministry of Youth and Sports of the Republic of Indonesia.2009.

Associated with the position of Indonesian students they occupy the position of problem and breeding in other words the student is the main source of Indonesian sportsmen who receive physical education activities in school as the basis towards the formation of self become a reliable athlete in then days.

Student Sports

There is no definitive definition of student sports yet the student's sport will always involve three things: sports education and sports achievements. Educational sports or known as physical education are organized every school that is covered in intracurricular.

The preparation of physical education material aims to: (1) develop physical skills that enable the individual to be able to carry out various daily activities, including developing neuromuscular coordination and perceptions of kinesthetics to move effectively and efficiently; (2) developing physical fitness that includes elements of strength, endurance, flexibility, and attitude development, (3) instilling knowledge and awareness about physical fitness, the principles of gestures and their benefits and inculcating healthy living habits, fostering strong willpower, critical thinking 
skills, creativity, perseverance and courage and self-confidence, (4) developing emotional skills and social talent for a person's success to be accepted, can play an active role in his environment, (5) develop a positive attitude and personality, a positive self concept.

The essence of physical education is part of education by providing the experience of the task of movement in order to foster the growth and development of learners thoroughly, and the purpose of physical education is; 1) Developing self-management skills in the development and maintenance of physical fitness and healthy lifestyle through various selected physical and sport activities, 2) Improving physical growth and better psychic development, 3) Improving basic motion skills and skills, 4) Placing the foundation of a strong moral character through the internalization of the values contained in physical education, sport and health, 5) Developing sportsmanship, honesty, discipline, National Sports Week,cooperation, confidence and democratic, 6) Developing skills to maintain personal safety, other people and the environment. 7) Understanding the concept of physical activity and sport in a clean environment as information to achieve perfect physical growth, healthy lifestyle and fitness, skill and positive attitude. Furthermore, the scope of physical education is: a) Games and sports include: traditional sports, games. exploration of motion, locomotor non-locomotor skills, and manipulative, athletic, kasti, rounders, kippers, soccer, basketball, volleyball, table tennis, tennis courts, badminton, and martial arts, as well as other activities; : body attitude mechanics, physical fitness National Sports Week, and posture and other activities, c) gymnastic activities include: simple agility, dexterity, tool dexterity and floor gymnastics, and other activities, d) rhythmic activities include: free movement, morning gymnastics, SKJ, and aerobic gymnastics and other activities; and e) Water activities include: water games, water safety, water-moving skills, swimming and other activities.

In physical education the main focus of learning is to learn to move, to learn different movements by studying in other fields. Learning to move not only demands physical involvement of students but also requires active psychological involvement. Therefore, understanding of motion learning, according to N. Drowaztky in Sugiyanto, learning motion is a learning embodied through muscular National Sports Week expressed in body movements or body parts While Yanuar concluded that motion learning is reflected by changes that are relatively permanent in appearance or potential behavior derived from past exercises or experiences in one situation. Furthermore a relative permanent change in appearance will not be represented by momentary fluctuations or inconsistencies but usually a well-done movement will persist for some time.

Referring to the above definition, the following conclusions can be deduced: (1) Learning to move is a process to gain a change of behavior is motion skills, (2) Learning movement involves physical and psychological aspects actively, (3) Learning motion starts from the ability to think, then proceed with physical activity in the sense of realizing what has been understood psychically (cognitive) into motor performance.

The second thing is recreational sports means by doing the sport the students will get a recreational atmosphere. Usually this sport is done in extracurricular contexts, the execution is like outdoor education, including: picnic / field trip, environmental introduction, camping, exploring, and mountain climbing. The third sport as expressed is the sport of achievement, in this case the learner will be involved directly in one of the branch sports that interest him. Usually the process of sports achievement among students is done in the form of extracurricular, where the implementation is the same as the exercise of the athlete in general that has a training program coach, training facilities, training goals such as championship match or competition.

\section{Public policy}

Some scholars provide an understanding of public policy such as Dunn (2003: 1), which states that public policy prioritizes what is based on collective, complex and interdependent patterns that are carried out not only by government officials but by government agencies overall. Then 
Gerston (1992: 5) states that public policy emphasizes more on the efforts decided by government officials at every level of government to solve public problems, then, Jones (1984: 47) Public policy can be seen from Ministry of Youth and Sports; (1) intention, is the actual intent or purpose of an action, (2) Goals, is the objective or final state to be achieved, (3) Plan or Proposal, is plan or proposal to achieve the goal, (4) (5) Decisions or Choices, is decisions or choices on actions taken to achieve the goal, (6) Effect, is measurable impact or influence. Nakamura and Smallwood (1980: 31) state that it is a series of instructions to policymakers explaining the objectives and ways of achieving that goal. It is further elaborated that public policy lies in the scope of policy, is policy formulation, policy implementation and policy evaluation.

Furthermore and Bromlay (1989: 32-34) states that the Policy process as a hierarchy. Public policy is a very important source of institutional change. In general there are three levels of institutional change process: policy (Policy Level), organizational level (level), and operational level (operational level). Policy process at each level will result in institutional arrangement in the form of legislation. Policy process at policy level will result in legislation which will be translated by policy process at operational level. If the result is less satisfactory, it usually involves a collective reaction through a process to improve the institutional arrangement. The policies relating to Student Sports are UU No 20 of 2003 on National Education System, Act No. 3 of 2005 on National Sport System Chapter VI Article 18, PP No. 16 of 2007 on the Administration of Sport Chapter VII article 25 through article 29, PP no 17 of 2007 on the implementation of the Week and the Sports Championships Article 22 to 25, PP No. 18 of 2007 on Sports Funding, Presidential Regulation No. 22 of 2010 on Indonesia Gold Program.

\section{METHOD}

This research was conducted by qualitative method, and was conducted for six months starting from July 2010 until November 2010 in North Sumatra.

\section{RESULTS}

It was found that ninety-nine processes of physical education teachers as well as trainers or coaches in schools are not aware of the national sportsmanship system Act, including the Government Regulations that are derived from the law. Most of the Ministry of Youth and Sports have heard of the presence of the Law, but have not read at a glance let alone the detail about the content of the Laws and Government Regulations governing the implementation of Sports.

These findings are illustrated in field notes indicating that some of the things that come true like the socialization of the birth of the National Institutes of Business Law and the following Government Regulations have not reached up to the sports actors to the forefront such as physical education teachers and school construction coaches in Sumatra North. The other realities are not yet optimally aware of knowing including finding out matters relating to government sports policies such as the National Institutes of Sporting System Act and Government Regulations on the organization of sports by physical education teachers. It was found that ninety-nine per cent of physical education teachers who are at the same time as coaches in schools are unaware of the existence of national policies on sports, especially those involving student sports.

Field notes of National Sports Week as physical education teachers explain that they have never been introduced to the actual form of government policy on national sports policies, especially policies on student sports. They have only ever heard of government programs and National Sports Committee of Indonesia as a form of national training camp which is known as Garuda Gold Program, Revive Phase Alternation Line Indonesia and even the current government program known as Prima (Gold Indonesia Program) only ever heard of the operational form of the implementation even though general. 
Furthermore, National Sports Week also explained that they have never known the existence of Special School Athlete in their respective regions or in the provincial capital but the National Sports Week are aware of the existence of the Student Training Center in North Sumatra which is located in Medan.

In relation to the Student Training Center North Sumatra in general the National Sports Week do not know the ins and outs of the Student Training Center North Sumatra starting from the recruitment system athletes trainers and managers and do not know the programs held in the Student Training Center North Sumatra but the National Sports Week understand that the existence of the Student Training Center is the channel of coaching achievement of student athletes.

Most National Sports Week want the Student Training Center starting from the age of junior high school and its presence is present in every district with the hope that the talents of the students in the field of sport can be well accommodated.

The findings in the field show that all National Sports Week are carrying out sports coaching activities in their respective schools. The field notes show that some of the athletes who were coached by the National Sports Week participated in the championships held at North Sumatra level and some even participated in the North Sumatra Sports Week 5 to 14 November 2010.

National Sports Week explained that they perform sports coaching achievement in schools in the form of extracurricular is the initiative of National Sports Week themselves in other words the activity is not based on the national sports policy made by the Ministry of Youth and Sports agencies or other agencies. Thus the implementation of sports activities achievement in pure school as the moral National Sports Week. Further explained the sports coaching channel of student achievement merely accommodates the willingness of some students who have interest and talent to be a great sportsman. Thus the work program training programs such as matches and so on National Sports Week can only hope that if there is no means the activity is only for the benefit of the students themselves.

The means used in the implementation of sports enhancement in the form of extracurricular students is a means owned by the school in general or used for ordinary learning activities. In other words no special equipment is provided for the benefit of the training process. Suppose there are tools that must be prepared for the purpose of coaching the achievements of the student athlete, the National Sports Week himself who seeks and with own funds.

The desire to promote the sport of achievement through extracurricular is very high, but faced with minimal means of infrastructure, which is related to sports science and technology. So that the use of science and technology sports for the advancement of sports performance in school is very much awaited with the sense of the presence of science and technology in sports among students is expected to generate motivation in the way to do better.

All National Sports Week were aware of the students' sports championship in the form of students' sports week organized at the provincial level, the students' sports week was sustained but forty percent of the National Sports Week stated that the student's sporting championship at the district / city level took place simultaneously so that when sending the team to the provincial level the selection pattern is done as little as possible.

Field records show that sports education activities are organized by following a pure curriculum issued by the national education ministry in other words the National Sports Week as a physical education teacher has a teaching obligation with a certain number of hours in accordance with the standard teaching hours of a physical education teacher who also depends on the number of classes and availability teaching staff at school.

Eighty percent of National Sports Week said they did not teach the entire content of the physical education curriculum at every grade level. The main reason for this situation is the inability of supporting facilities to complete the curriculum demands both in quality and quantity. As an 
example in the curriculum there is javelin throwing lessons, but in reality learning in school there are only one or two pieces, so the lesson about the javelin is not implemented

The field notes also show that in essence the innovation of National Sports Week has not been qualified in solving the existing problems by utilizing the existing infrastructure to complete the contents of the curriculum, so that the topic of physical education subject to futsal, basketball and swimming games that impact not all students are active in physical education activities.

The field notes show that not all National Sports Week host recreational sports at school, there is only one school that organizes aerobic exercise as a form of recreational sport in its school. National Sports Week have heard of outdoor sports such as excursions, hiking, outbound, and others, but National Sports Week often bumped into licensing issues from either the principal or the parents.

\section{DISCUSSION}

Law No. 3 of 2005 on the National Sport System is established as an official sports law umbrella applicable nationally. This Act contains all forms of movement in the field of sports in Indonesia. As a legal umbrella, all human sports in Indonesia understand, to know. Following all the chapters and verses that overshadow the scope of life of the country's homeland. Hope the law makers and government regulations are actively involved all parties advance all forms of sports life nationally.

As the creator and creator of national sports policy in the form of National Health System Law and Government Regulation should in all ways maximally be able to convey the full and complete laws and regulations of the government to all parties of sports ranging from the level of policy makers to the level of executing at the lowest level. A strong understanding of the policy helps every supporters prepare himself and position himself in acting or doing anything in the sport. Socialization can be done in various ways such as leaflet or book distribution, socialization in a chain and thorough, or in other forms of action, so that the supporters at all levels will be helped when trying to build the quality of sports either in the form of quality management, organizing or achievement of results.

Parties to the sport in this case physical education teachers or coaches sports in the national sports school schools. Some important things such as the rules that set in North Sumatra are still not appreciative of the important things that happen in sports life in Indonesia, which is now in the form of laws and government regulations, books related to sports both sports achievements, recreation, and other documentation education that is deemed necessary to assist the performance of the sport actors.

Appreciation that is not yet optimal is still to be sought for cause, but there are allegations that lead to curiosities that tend to be less, less available facilities or access that is difficult to penetrate. However, sports should prepare to equip or fix themselves about all forms that enrich him when struggling with his job at work both as a physical education teacher and as a coach of sports in school.

In addition to Indonesia's national sports law policy, in the form of active action on the ground in the form of programs, Indonesia once had a National Training Center, the Center for Student Education and Training, Student Education and Training Center, Special School Athletes, Garuda Gold Project, Indonesia Rise Program, Mainline Athlete Program and currently underway There is a national sports policy that once existed in Indonesia national sporting order. Of course the spectacular policy is the presence of the National Sports System legislation along with the government regulations concerning or in the form of a derivative of the sportsmanship law. This policy tends to be more like a sports law policy that acts as an umbrella of Indonesia's national sports law.

Some government policies in mobilizing the progress of the country's sport stop in the middle of the road like National Training Center, Garuda Gold Project, Indonesia Rise and Phase Alternation Line. In other words, the government's current sports policy is Prima supported by Presidential 
Regulation no 22 of 2010. In the presidential regulation, the Student Training Center, sports school, and school clubs are in PRIMA program.

The existence of the Student Training Center which is only one in North Sumatra which is so wide, and has good potential, is of course very limited in accommodating the gold potential of students in North Sumatra. In addition to its limited sports, as well as the availability of capacity. So hopefully a new breakthrough such as the establishment of the Student Training Center in the capital and the expansion of the number of sports.

The other side that does not yet exist seems to be school clubs that are managed professionally, in other words the establishment of a school club is still just a discourse and expected as soon as it may appear. The reason that it is still in a mere discourse is that there has not been any form of guidance or guidance for the establishment or establishment of a school sports club containing all the chaotic management such as funding recruitment funding system and so on. The organization of sports education, also known as physical education in school, takes place with a curriculum guide issued by the Ministry of Education. The implementation of the sport of education, apparently not yet leading as a support build or prepare the basics to be a sportsman achievement. This fact is possible that the curriculum content is not yet optimal towards the preparation. The continuity of the exercise of education or physical education has not been touched by a policy or program assistance from the Ministry of Youth and Sports. The acceptance of the program will be more organized or enriching physical education. Thus the implementation of physical education in the school of North Sumatra is still purely following the curriculum of the Ministry of National Education.

The implementation of recreational sports in schools in North Sumatra is intrinsically incorporated in extracurricular activities. However, the explanation shows that not all schools have organized recreational sports for the students. Understanding of recreational sport is only the hiking and camping that has been managed by Scout units.

The sports organizer of student achievement in North Sumatra explained that unless the management of the Student Training Center, the implementation of sports achievements directly in school has not been managed institutionally. In other words, the implementation of sports achievement of the students in the school is not structurally structured, or implemented only because of the moral wishes and National Sports Week of physical education teachers in the school.

Physical education teachers assigned to one school as well as acting as trainers on extracurricular activities, and the selection of auxiliary sports are in accordance with the capacity of the physical education teacher referred to, so that if the physical education teacher does not have special skills in a small sport the qualified extracurricular possibilities can be found. .

In essence the resources of athlete candidates already owned by each school live how the mechanism of management of extracurricular sports activities become more qualified, such as presenting special trainers of sports with civil servant status in each school. Of course the presence of these trainers will be more exciting as well as further improving the quality of extracurricular in every school. With such a tidy order will undoubtedly bring more people excel in the field of sports. Another important thing to note is the provision of training facilities that are still far from the support of Science and Technology sports so that such initial data are needed in the effort to form a reliable athlete wasted away when the data base is badly needed when a student will one day wrestle himself into an athlete.

This fact may not have been socialized guidelines or guidelines or similar things in the management of student sports in the school environment in North Sumatra. Sports championship or sports week is the fastest medium in measuring the progress of a sporting achievement. At the sporting championships will be displayed physical techniques, tactics and mental endurance of the sports or in other words sports championship is the arena of real rules for every sportsmanship. The 
lack of sports championship media will affect the first lack of knowledge of the actual progress of training that has been done by the coaches of school sports. The second will also affect the motivation to participate both by the students themselves and by the his coach own. Third will impact on talent scouts that should be easy to find talented athlete candidates in the arena of student sport championships.

\section{CONCLUSION}

1) Need to optimize the socialization of Law no. 3 of 2005, Government Regulation no. 16, 17, 18 socialized among sports actors such as physical education teachers and coaching sports students in North Sumatra communicatively. 2) Socialization of National Sport Programs or Projects such as Prima as stipulated in Presidential Regulation no. 22) in 2010 to all levels of sports actors such as physical education teachers and coaches in North Sumatra communicative, chained and qualified. 3) There should be a sports education program in the schools issued by the Ministry of Youth and Sports, 4) Need to make guidance or sports manual recreation of students issued by the Ministry of Youth and Sports, 5) Need to be made and socialized guidance of coaching or establishment and management of sports achievement of students issued by the Ministry of Youth and Sports, 6) Need to be optimally empowered Board of Trustees of Student Sport throughout Indonesia presence in all districts in North Sumatra 7) It needs to be done by working with provincial government Branch of Sports with Department of Education and Youth and Sports Office in North Sumatra about the implementation of the championship or Sports Week, 8) Need to realize the procurement of sports science and technology in schools that foster sports in North Sumatra in accordance with the requirements 9) It is necessary to realize the Student Training Center in the district level of the city in North Sumatra to accommodate the talent interests of the sports achievers, 10) The need to realize the presence of special trainers of sports with the status of civil servants in schools in North Sumatra, 11) Need to be realized sports championships or students' sports week at every level of the city districts periodically and continuously, and 12) Regular physical upgrading of physical education is required for the enrichment of teacher competence in northern sumatra.

\section{REFERENCE}

Djaali. (2000). Measurements in the Education Sector. Jakarta: PPS UNJ.

ICE. Quade. (1982). Analysys for Public Decision. New York Elsevier Science Publishing .

Eguene Bardach. (2000) A Practical Guide to Policy Analisys The eight Paths in More Effective Problem solving. New York: Seven Bridge Press.

James R. Randers, et all. (1994). The Program evaluation Standards. Second edition. California Sage Publication, Inc.

Ministry of Youth and Sport of the Republic of Indonesia.(2009). National Sporting Agency Governance Guidelines.

LN Gerston. (1992). Public Policy Making in a Democratic Society. A Guide in Civic. Engagement New York: Sharp. ME Inc.

Munandir. (2009). Kapita Selecta Education. Jakarta: AV Publisher.

Ngalim Purwanto. (2007). Science Education Theory and Praktis. Bandung: Remaja Rosdakarya.

O. Jones. (1984). An Introduction to the Study of Public Policy. Ricky Rianto's translation. Jakarta: PT Raja Grafindo Persada.

Prayitno. (2009). Basic theories and Praxis of Education. Jakarta: PT. Gramediawidiasarana Indonesia.

Riant Nugroho. (2004). Public Policy, Formulation, Implementation, and Evaluation. Jakarta: Gramedia.

RT Nakamura and F Smallwood. (1980). The Public of Policy Implemantation. New York: St. Martin Press.

Rusli Lutan. (2001). Principles of Physical Education, Motion Education Approach at Primary School Jakarta: Depdiknas.

S. Sunggono. (1994). Law and Public Policy. Jakarta: Sinar Ghalia. 
Stufflebeam L. Daniel. (1996). Systematic Evaluastion. Kluwer Academic. Publisher Group Bosston / The Hague / Dodrecht / Lancaster.

Sugiyanto, Sudjarwo. (1986). Development of Learning Motion. Jakarta: Depdikbud.

Thomas L. Good \& Jere E. (1990). Brophy, Educational Psychology A Realistic Approach. New York.

William M. Dunn. (2003). Public Policy Analisys. An Introduction. Second Edition. New University Press.

Yanuar Kiram. (1992). Learning Motorik. Jakarta: Depdikbud. 